\title{
GAME DESIGN AS LEARNING MEDIA OF ENGLISH PRONUNCIATION USING SET COLLECTION MECHANICS
}

\author{
Jonathan Andrian Timothy \\ Visual Communication Design, Satya Wacana Christian University \\ e-mail: dingdongisback@gmail.com \\ Tan Arie Setiawan Prasida \\ Visual Communication Design, Satya Wacana Christian University \\ e-mail: arie.setiawan.p@gmail.com \\ Jasson Prestilliano \\ Visual Communication Design, Satya Wacana Christian University \\ e-mail: jasprelao@gmail.com
}

\begin{abstract}
English is an official language used to communicate between countries. Indonesia also learns English that can be learned from elementary school or kindergarten. However, pronunciation or pronunciation still bears serious mispronunciation, both vocalization, emphasis, and overall. Reliance on English has complexity and technique that the Bahasa pronunciation does not have. The problem with research is strategy and developing of a board game to learn English - speaking techniques. The purpose of this research is to design a learning media of English pronunciation through board game. This research uses experimental methods, linear strategies and combination approaches. The sources for this study are studies, books, interviews with professors and students. This research is about learning pronunciation using board game as a media. The purpose of this study is to design a game board called the Word Detector as a learning media. The result of this study is an increase in the result of the learning process performed before, after and several days after playing a board of games "Word Detector."
\end{abstract}

Keywords: learning media, English pronunciation, board game

\section{INTRODUCTION}

Due to readiness in terms of English language skills, Indonesia is still in the low category. Recorded in the 2018 Education First English Proficiency Index (EF EPI) test which this test involves listening ability, Indonesia had gone down to rank 51 with a value of 51.58 (Low Proficiency). In contrast to Indonesia's score in 2017 at number 39 with a value of 52.15 (Low Proficiency). Based on the score that included in the Low Proficiency category, EF EPI also provided several insights to maximize English language skills including English speaking as a tourist, understanding messages from colleagues who are English speakers, and using English speaking in light activities with relatives.

From this case, it can be seen that basically Indonesia has quite good English skills. But it is not practiced in daily life because English is not the first or second language in Indonesia. EF EPI encourages countries with Low Proficiency values to be more active in using English speaking to improve their ability to speak English. To 
understand how to do English speaking well, the country must be ensured to have good English Pronunciation skills.

Pronunciation is one of speaking skills that can be directly observed and known. When someone speaks in English, the person who is listening will immediately understand how the pronunciation of the person is. When someone makes a mistake in their English pronunciation, it will be immediately known the person has a good word or grammar.

The difference between Indonesian tongue habits and native speaker (people who speak English as a mother language) is the cause of frequent mistakes in English pronunciation (Astini, 2013). English has more variations and rules for speaking than words in Bahasa. While Bahasa are less accustomed to the English pronunciation rules or can be called being native or native speaker. To learn English pronunciation correctly requires a teacher who is quite skilled in teaching pronunciation. But not every time someone will get the knowledge and guidance of pronunciation. Someone will be confused in mentioning a word that has never been taught and as the result it can make miss-pronounced the words (Azzahroh, 2015).

In order to check whether the spelling of a word is correct or not, it is necessary to check using phonetic transcripts such as those listed in English dictionaries in general. The rules of British English will be used as a basic reference in choosing the type of English due to its history and development British English holds the earliest history and has the most standard rules (Hogg, Richard, \& Dennison, 2006). Phonetic transcription in English consist of consonant and vowel sounds that are not familiar in Bahasa. Then this phonetic transcription also provides information about the emphasis of a word that is located in certain syllables called Word Stress. Different Word Stress will give different meanings even though it is the same word and the root word which added by affix if it is interpreted into Bahasa. Whereas Word Stress in Bahasa does not change the meaning of the word. Then the phonetic transcription also provides information where a letter will not be heard if the word is pronounced so-called Silent Letter. Whereas all words in Bahasa must be clearly pronounced.

Learning media are specific tools used as learning that have a certain impact on their learning activities and outcomes. Learning media can be text, visual, video, manipulation and people (Smaldino, Lowther, Russell, \& Mims, 2008). Learning media have a way to convey material messages, which can be visual, auditory, and kinesthetic. The game board has all of these criteria where the player can see the game, make a few conversations with other players and can touch the game itself. In general, the use of instructional media has been used to clarify the presentation of messages to be less verbal (in the form of written or spoken, and to overcome the limitations of space, time, senses, such as objects that are too large can be replaced by pictures or models, and concepts which is too broad can be visualized in films or pictures. (Setyanugraha \& Setyadi, 2017). Board games can be regarded as one of the media. The reason board games are right to be a medium for learning pronunciation is because someone can play it as a good learning after school or work. The benefits of playing are to encourage physical growth or development, cognitive, social, emotional, being children, creativity and brain development. It also increases parental involvement in activities that indirectly train children to work in groups, share and negotiate conflicts. (Yunita, Wibowo, \& Aryanto 2013).

Board game has good potential in language learning and it can provide motivation for students who are passive and active to be more active (Dolati and Mikaili, 2011). 
Therefore this research is intended to study how to pronounce English vocabulary correctly both intonation, word emphasis, and silent letters through board game media.

Previous research that had discussed board game as an English language learning medium was Rizky Amalia Azzahroh, entitled The Effectiveness of using Board Games toward Students Speaking Skills. The research results in differences in the value of English for classes using games in the form of quizzes in the snake-ladder game by providing certain topics that are appropriate for the child's learning. Another research was also carried out by Lia Amalia Nirmawati, entitled Improving Students' Speaking Skills Through the Games of Grade VIII Speaking Board of SMP N 13 Yogyakarta in the Academic Year of 2013/2014. The study discussed how to lure students to communicate in English according to certain materials. However, both studies have not yet taught the basic technique of pronunciation.

Based on the analysis, the board game pronunciation design can be carried out with the terms of British English rule references. The focus of the board game material will also contain the pronunciation and phonetic techniques.

\section{METHODS}

The research method will use a mix method. This method will include a combined approach between qualitative and quantitative methods. The purpose of using a mix method is to overcome the shortcomings that exist in the results of quantitative and qualitative methods. A linear strategy is a combination of data that results in new data that is easier understood (Sarwono \& Lubis, 2007). Figure 1 shows the diagram of the research stage.

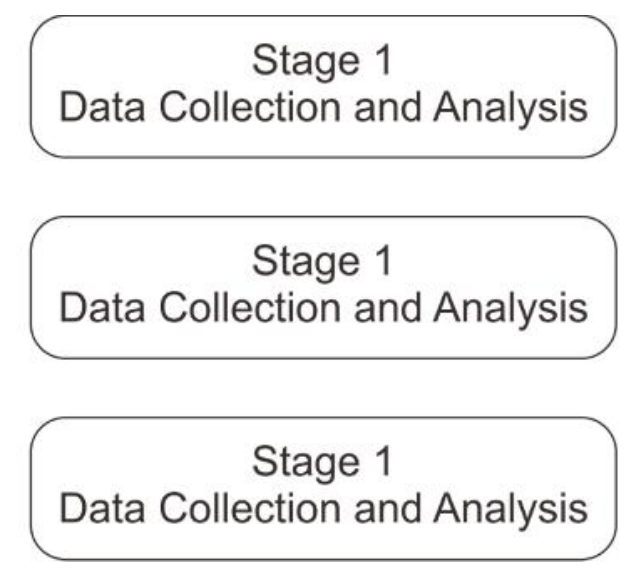

Figure 1. Research Stages Diagram

Data collection will use qualitative data collection. Primary data will be conducted by interviewing SWCU FBS teaching lecturers who focus on teaching of speaking skills. Then the collected data will be analyzed to be a reference in the board game design process. The board game design stage refers to the Game Design Process from Ceo Kummara, Eko Nugroho. The game design process itself will include the concepting phase, design phase and production. Figure 2 shows the flow of the Game Design Process. 


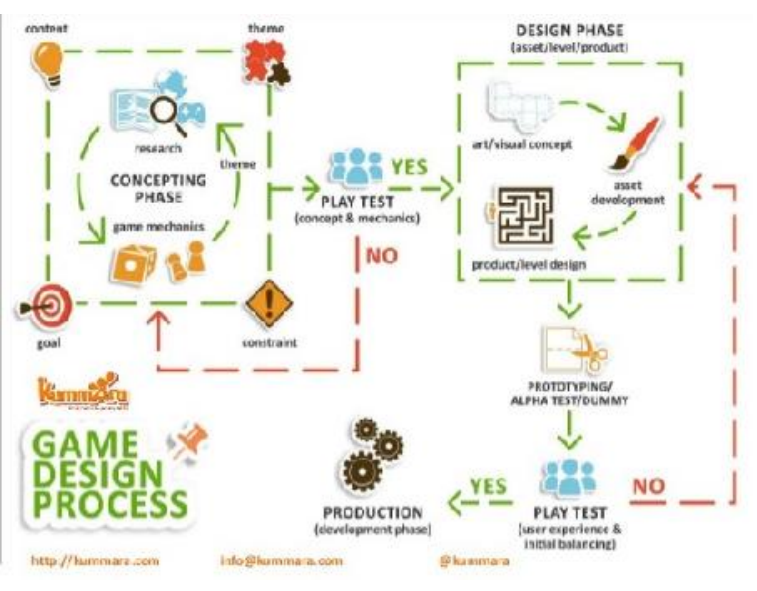

Figure 2. Game Design Process

In the concepting phase all data analysis will be used to determine game mechanics, game objectives, required components, and game rules. In the design phase it is necessary to make a prototype game to find out the flaws in the game. Furthermore, the game board is ready for production and will soon go through the testing phase.

The test will be conducted with an experimental approach to find out how effective the use of board games for learning pronunciation. The test was conducted in 2 meetings. The first meeting is a test conducted before playing board games and after playing board games. The next meeting takes 7 days after the first meeting to find out how far the player's knowledge has progressed.

\section{RESULT AND DISCUSSION}

This discussion will outline the process of collecting data to look for board game concepts, designing board game material concepts, and testing board game materials.

\section{Data Collection and Analysis}

Data collection is intended as basic information about pronunciation techniques in English which will be summarized into the concept of board games. Data collected qualitatively. Qualitative data collection was obtained from interviews with Ms. Gita Hastuti, S.Pd., MA, as a lecturer at the Satya Wacana Christian University Language and Arts Faculty that focuses on Speaking and Conversation, five SWCU FBS students and four XII grade high school students with different educational quality levels.

The interviews with lecturers result showed that the new students in pronouncing the English was still mixed with the dialect of their respective regional languages although later on they would learn more in the end to be trained more natively. Meanwhile, to look for how the word is pronounced, it can be seen in the phonetic transcription of the word on the dictionary.

The results of interviews with high school students grade XII also showed that during English learning in high school there was no special material on pronunciation or profound pronunciation techniques because they had to be demanded to remain focused with the preparation of materials and grammar. This makes students confused and forced to read without a certain rhythm and intonation. But the teacher will still teach you how to pronounce the difficult words. 
The results of the SWCU FBS student interview showed that there are many pronunciation techniques that had not been learned during high school, which also resulted in repeating classes that focused on speaking, reading, and listening. The number of word stresses, silent letters, vowels and certain consonants also becomes an obstacle because in Bahasa different intonations will be able to know the person's intentions and emotions. But in English the difference or the addition of affixes to a word will make the pronunciation will be different even though the word consists of only one root word. Meanwhile, to practice these techniques only rely on material from lecturers or try to listen from certain dictionary applications or book modules provided to students. The effect students will expect not to repeat without understanding the correct application of the pronunciation of certain words.

From the interviews with lecturers, high school students, and SWCU FBS students, it can be concluded that learning the pronunciation technique is not easy and becomes unattractive. The pronunciation technique learners need media that can provide material in an interesting and interactive way. Educational game media can be a solution for learning pronunciation because it is difficult to be able to understand the material for some students and will be a separate provision for high school students.

The results of data collection were analyzed and then summarized into concepts according to material needs. Learning media that are designed must be in accordance to the specified concepts, become learning solutions and the results of the design can be conveyed properly. Qualitative data is used as a reference for learning media, which can be an effective, innovative, and attractive learning media for students to learn pronunciation, so it is a good way to increase the level of students' understanding of English pronunciation. Media also must be simple and easy to understand so that it can be applied in the learning process and outside the learning process.

The principle of learning includes three learning aspects that consist of cognitive, affective, and psychomotor as well as three learning modalities such as visual, audio, and kinesthetic (Avianto, Yovita \& Setiawan, 2018). Games are often considered as activities to fill leisure time without a specific purpose. But now, there has been a change of view of play, due to the study of aspects that can be contributed through playing for the learning process. Scientists claim that playing is a valuable learning experience. According to child psychologists from Three Generations, there is research that states the game can train children's abilities, including the ability to think, language, motor, and hold emotions (Christian \& Pariwisada, 2018).

From this summary, board games can be an effective alternative learning media. Board game can be played in groups anywhere, has interesting visuals, and can help the learning process. This is because among players can discuss during the game. The difference from the use of other learning media is that board game has several advantages, such as producing two-way communication between directly. Examples of film or video media that produce one-way communication that is students only listen and pay attention to what is shown. In addition, board games can also build reading skills because to be able to play board games, students must understand the course of the game by reading the guide how to play or rulebook first.

Set Collection is a category that is used in board games that are designed, because this category relies on collecting certain information related to the ultimate goal of the game. The difference with conventional books is that the collection set can practice the development of player information by itself because the player can immediately find out 
which information matches the end of the game, so the use of this category for pronunciation learning is appropriate.

\section{Board Game Design}

Starting to enter the concepting phase, the data collection and analysis stages begin to be processed into material that will be implemented in the board game design. Existing materials are then processed into concepts. The concepts used and simplified include the objectives and basic rules of the game, game mechanisms, and game story. This concept is based on the basic elements of game design which will then be developed and refined in the next phase (Tangidy, Alez \& Setiawan, 2016).

The basic purpose and rules of the game are to look for clues that related to words that players will draw in the future and these clues must be relate to words obtained by players both from pronunciation, and related objects. Then, after one of the players managed to get a clue that matches the word, the player must recite the word, then the other player will judge whether the pronunciation of the word is appropriate or not. The game will end if one of players who have completed a certain number of words.

The story in this game is that the player will act as a local policeman who is helping children to find the truth of a pronunciation of certain words in their respective areas. The police with the highest points can determine the next set of words. Later the scattered instructions can be checked using applications that must be installed on the gadget. Then the title "Word Detector" was formed. Determination of the title based on the existing game gimmick on the game board. The list of words chosen was also taken from interviews with class XII students and SWCU FBS students by giving 1 word that was quite difficult to pronounce and easy to pronounce.

In accordance with the existing concept, it is necessary to do a playtest. Playtest is a process carried out to know the advantages and disadvantages that occur in the game during the course of the game. Parts of the game that change only in aspects where there are parts that are not appropriate or not in accordance with the expected concept. Appropriate parts do not need to be replaced although they may still be developed. This process will be repeated until the game is deemed appropriate and in accordance with the purpose of the game. Playtest is done using prototype with HVS paper material and only written in pencil, so that repairs are easier and faster to do. By using a prototype, the process of analyzing the system can obtain initial results from the user so that it allows for better improvements to the product to be made (Saputro, 2016). Prototype Word Detector can be seen in Figure 3.

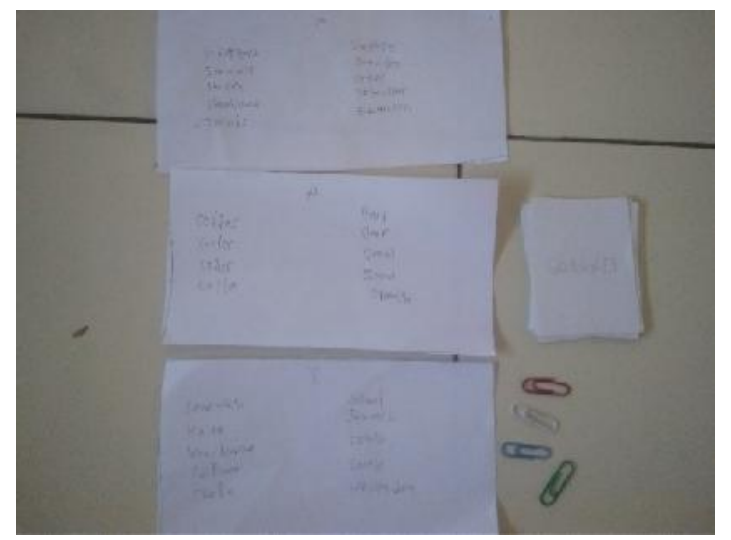

Figure 3. Prototype Word Detector 
At the prototype stage, there is a problem in the completion of the game that is if the game is played without a validator. It takes an example of pronunciation that can be a reference as a validation of the players. Whatever the pronunciation results of these players, if the pronunciation is not in accordance with the results of the recording, the player does not get points, an audio file that can be recorded and used during the game is needed, so the sound recording process is needed from a colleague who is an expert in English pronunciation, a native speaker, and this will also add a prototype to design a simple application. Android Studio The prototype application sketch can be seen on Figure 4.

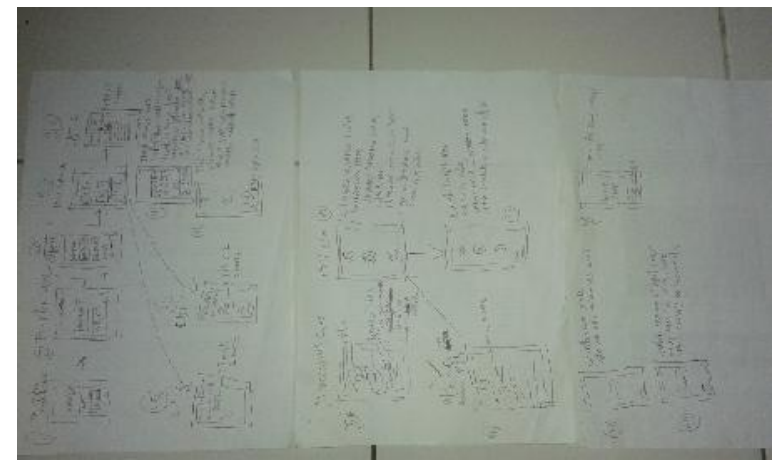

Figure 4. Prototype Application Sketch

The application is designed and illustrated according to the themes and illustrations on the components of the game board. The design of the application must go through a testing process so that no errors or bugs are found when the player will use the application. After the application can be used, the next process is to create a link that will connect the player to the application installation using a barcode. The function of this barcode is to access the player to get the installation of the application by scanning. The display page of the application can be seen on Figure 5.

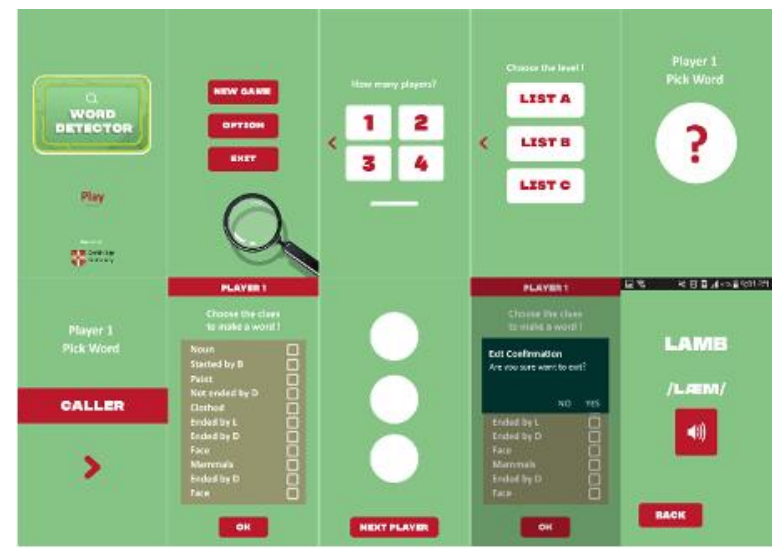

Figure 5. User Interface 
In the Design Phase, the concept is deepened again. Card names such as clue cards become clue cards, boards containing words are made into boards as game areas. The first region will contain words that practice vowels and consonants. The second area will contain silent letter material and the third region contains word stress material, then the word markers will be changed to player tokens, then enter the balancing process, which aims to ensure the game is neither too easy nor too hard. In this design phase, the prototype is equipped with simple illustrations, such as the use of images, writing, and settings the layout of the pictures and writing on the card as a rough description of the end result of the board game, display illustrations and the layout of the writing continues to be improved in accordance with the results of the playtest, until it feels good.

In the Development Phase, illustrations and colors on components are adapted to the concept. Handbooks on how to play, package, and display board game applications are also designed according to the concept so that it is easy to understand when played. At this stage, the design of each component of the Word Detector board game has been completed and is ready for final testing of the research targets, namely students of class XII high school and equivalent students. The total number of clue cards is 56 clue cards, with the number of each card that is 60 Script Cards with 19 clue cards each for region A, 16 clue cards for region B, and 16 clue cards for region $C$. The final result of the Word Detector component can seen on Figure 6.

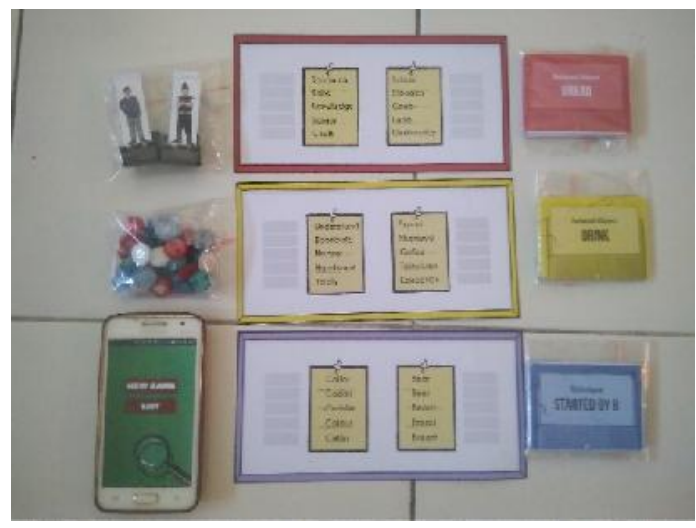

Figure 6. Word Detector Component

In the manual there is a brief description of the game, the story of the game, components, how to prepare the game, how to play, the end of the game, and the circumstances of winning and losing and also how to use the application. The results of the guidebook design can be seen on Figure 7.

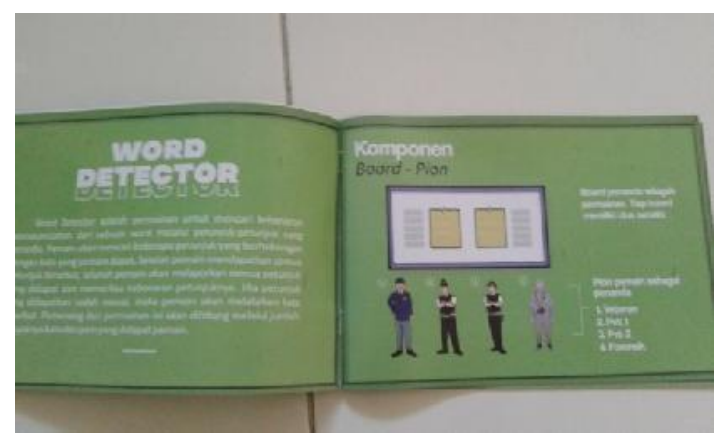

Figure 7. Word Detector Rulebook 
In the upper packaging there is a logo and game board title, packaging illustrations, game designer names and illustrators of the Word Detector game board. The bottom packaging contains the game logo and title, illustrations of some game components, a brief synopsis of the game, description of game duration, number the player, and the player's age, and the barcode for installing the application. The design of the top and bottom packaging can be seen on Figure 8 .

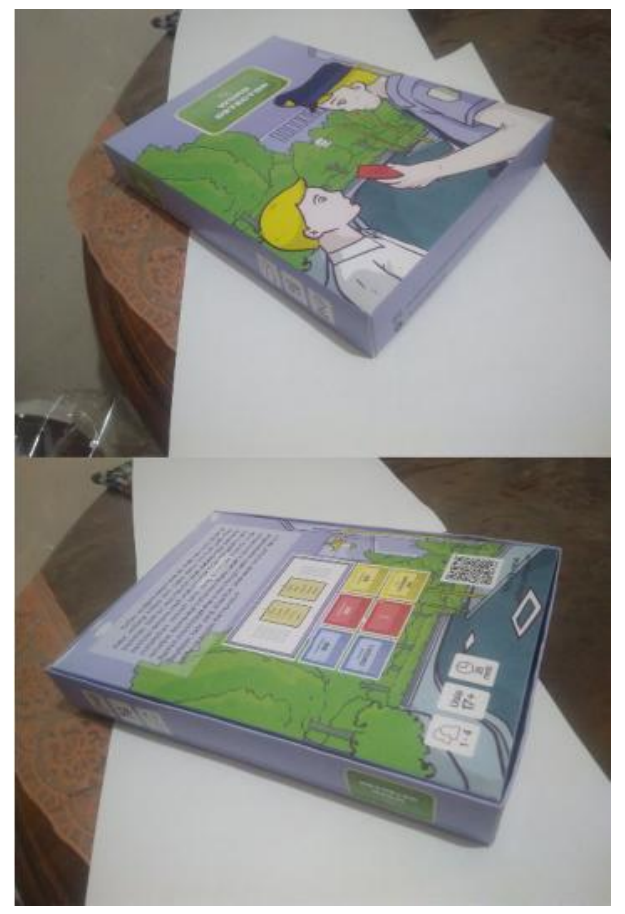

Figure 8. Packaging Design of Word Detector

\section{TEST}

After experiencing various stages of playtest, the board game is ready to be tested on students. The target age of this game is 17 years with a number of players from 1 to 4 players. Before testing the research targets, the board game is tested on Indonesian board game design experts. Based on the results of an interview with Erwin Jarot Skripsiadi, the designer of the Yogyakarta and Celebes game board game, the results were obtained that the game play is very easy because the game duration is not too long and players can see the translate on the rulebook if the player doesn't know the meaning of each word in the game, he also added the use of the application as a validator can also help players if there are differences of opinion on the results of pronunciation between players. Testing with him can be seen on Figure 9. 


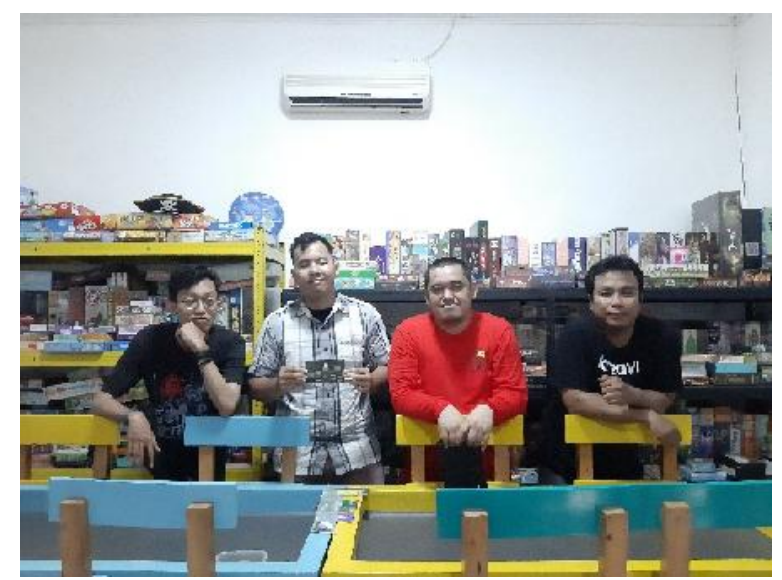

Figure 9. Test of Board Game with The Expert

The test is continued to the research target which consists of students from different faculties and 2 schools with different quality of education. Testing will be conducted in 2 meetings. The meeting will be in the form of pre-test (Testing 1), playing board games, and postings test (Testing 2), while the next meeting is only a post-delay test (Testing 3) and questionnaire Delay post test is conducted to find out the extent of the player's understanding of pronunciation both after playing and after a few days not being played. is 7 days. The final testing process of the Word Detector board game can be seen on Figure 10.

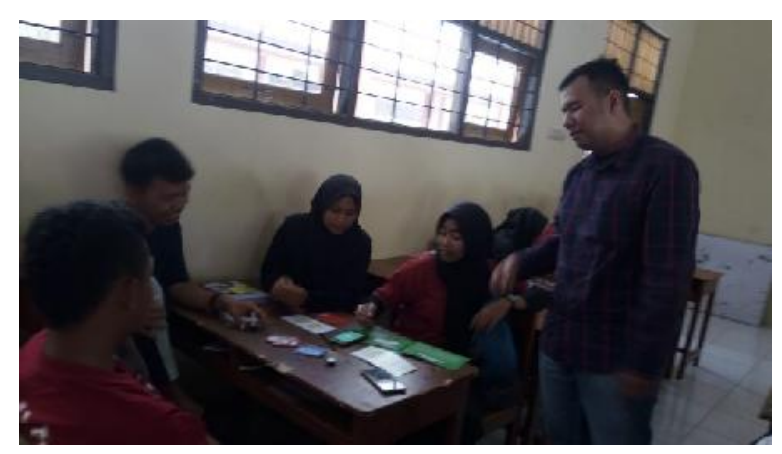

Figure 10. The Testing of Board Game Word Detector

Quantitative data is obtained through the results of listening test scores, assessment will be simplified according to the number of questions from numbers 1 to 30. Then the test results are described based on the results of the test type. Table 1 is the average result of each test.

Table 1. Average Test Results According to the Type of Test

\begin{tabular}{lll}
\hline Pre Test & Post Test & Delay Post Test \\
\hline 17.19149 & 19.80851064 & 19.42553191 \\
\hline
\end{tabular}

A summary of the average listening test results showed an increase in the value of the pre-test results (before playing board games) and post-tests (after playing board games). It showed that learning media using board game media can improve player 
learning outcomes. There is a decrease in the value of the post-test delay value (testing at the second meeting) with the post-test value, the results of the post-test delay value are still higher than the pre-test value, it showed that although the material was not discussed within one week, the learning results from the board game still controlled by that way the board game media could be said to be effective as a medium for learning pronunciation.

DePorter \& Hernacki (2001) stated that the learning process is effective if learning is fun. The atmosphere like when testing was considered effective and needed in the classroom so the learning process was not boring. Players could also explore new words, compete for the right answers, and want to be considered right after listening to the recording to get extra points. It indicated the enthusiasm of players during the learning process while playing didin't not reduce concentration in understanding the material. This could also be known through the results of the questionnaire containing several questions, including (1) starting to understand pronunciation techniques, (2) interesting as a medium of learning, (3) how to play is easy to understand, (4) the application on the game board helps provide an assessment of the instructions. The results of the questionnaire could be seen in Table 2.

Table 2. Student Questionnaire Results

\begin{tabular}{|l|l|}
\hline Begin to understand the pronunciation technique & 41 \\
\hline Interesting As a medium of learning & 43 \\
\hline Easy to play & 39 \\
\hline Application Works well during game & 45 \\
\hline
\end{tabular}

Based on the results of the questionnaire from 47 players, it could be said that the players can learn pronunciation easily and fun. Technically, the players also felt that they have never been taught techniques or how to read a word in detail, only focusing on the meaning of words and school material. the player also gave an opinion for the Word Detector board game to teach pronunciation material well.

\section{CONCLUSION}

Pronunciation is the first step that should be taught to someone before learning English due to differences in the use of vowels, consonants, and varying emphasis on certain words. But this is not given much attention in the Indonesian English education system. The result is that only children get more educational facilities that can master English pronunciation with notes will produce a different English accent too later.

The Word Detector game board can be an option for learning pronunciation techniques both inside and outside of school. Using the application can also help the player when the players can't decide what the correct pronunciation of certain words is like. Thus, the Word Detector board game can be used as a formal and informal learning media.

\section{REFERENCES}

Astini, R (2013). Belajar Bahasa Inggris Pronunciation. Retrieved from https://www.englishcafe.co.id/belajar-bahasa-inggris-pronunciation/ 
Avianto,Yovita dan T Arie Setiawan. (2018). 'Pembelajaran Aksara Jawa Untuk Siswa Sekolah Dasar Dengan Menggunakan Media Board game'. Jurnal Aksara.30(1), hlm. 133-148

Azzahroh, R. A., (2015). The Effectiveness of using Board Games toward Students Speaking Skill. Universitas Islam Negeri Syarif Hidayatullah Jakarta.

Christian, I.V., dan T.A.S. Pariwisada. (2018). "Developing Board Game as Learning Media about Waste Sorting for Fourth Grade Students of Elementary School". Jurnal Prima Edukasia, 6(1), hlm. 78- 80. Retrieved from doi:http://dx.doi. org/10.21831/jpe. v6i1.17148

DePorter, B., \& Hernacki. (2001). Quantum Learning: Membiasakan Belajar Nyaman dan Menyenangkan. Bandung: Penerbit Kaifa.

Dolati, RI., \& Mikaili, P., (2011). Effects of Instructional Games on Facilitating of Students' Vocabulary Learning. Australian Journal of Basic and Applied Sciences, 5(11), hlm. 1218-1224.

Hogg, Richard., \& Dennison, D (2006). A History of the English Language: Cambridge University Press.

Nirmawati, L. A., (2015). Improving Student's Speaking Skills Through Speaking Board Games of Grade VIII OF SMP N 13 Yogyakarta in the Academic Year of 2013/2014. ePrints@UNY Lumbung Pustaka Universitas Yogyakarta.

Sarwono, J., \& H. Lubis. (2007). Metode Riset Untuk Desain Komunikasi Visual. Yogyakarta: Andi.

Saputro, D. A. (2016). Perancangan Media Edukasi Kandungan Berbahaya Junk Food bagi Anak Sekolah Dasar dengan Menggunakan Teknologi Augmented Reality Berbasis Android. Salatiga: Universitas Kristen Satya Wacana.

Setyanugrah, F., \& Setyadi, D. I. (2017). Perancangan Board Game Sebagai Media Pembelajaran Mitigasi Kebakaran Untuk Anak Sekolah Dasar Usia 8-12 Tahun Di Surabaya. Jurnal Sains dan Seni ITS, 6(1), hlm. 62-68.

Smaldino, S. E., Lowther, D. L., Russell, J. D., \& Mims, C. (2008). Instructional technology and media for learning.

Tangidy, Alez dan T Arie Setiawan. (2016).'Toleransi Melalui Model Budaya Pela Gandong Menggunakan Media Board Game untuk Mahasiswa'. Jurnal Kajian Kebudayaan. 11(2), hlm. 16-25.

Yunita, Y., Wibowo, W., \& Aryanto, H. (2013). Perancangan Permainan Interaktif Melatih Manajemen Waktu Untuk Anak-Anak Berusia 6-8 Tahun. Jurnal Desain Komunikasi Visual Adiwarna, 1(2). 